\title{
レーザ測長機を用いた高精度ロール測定装置の開発* (多点反射による感度向上)
}

\author{
中藪 俊博 ${ }^{* 1}$, 岡田 将人 ${ }^{* 1}$, 浅川 直紀 ${ }^{* 1}$, 金丸 裕 ${ }^{* 2}$, 廣㟝 憲一 ${ }^{* 3}$ \\ 田村 陽一 ${ }^{* 3}$ ，谷内 秀夫 ${ }^{* 4}$ ，清水 昭裕 ${ }^{* 4}$ ，川原 寛之 ${ }^{* 5}$ ，天谷 浩一 ${ }^{* 6}$
}

\section{Development of a precision laser interferometer for roll measurement (Enhancing of sensitivity by retroreflection methods)}

\author{
Toshihiro NAKAYABU ${ }^{* 1}$, Masato OKADA, Naoki ASAKAWA, Yu KANAMARU, \\ Kenichi HIROSAKI, Youichi TAMURA, Hideo YACHI, Akihiro SHIMIZU, \\ Hiroyuki KAWARA and Koichi AMAYA \\ ${ }^{* 1}$ Kanazawa University, Institute of Science and Engineering \\ Kakuma-machi, Kanazawa, Ishikawa, 920-1192, Japan
}

Received 21 November 2013

\begin{abstract}
Almost all geometric deviations that occur on a machine tool can be detected most precisely with the laser measurement system. However, the roll cannot be detected yet since the interferometer for it is not present. The purpose of the study is to propose a practical laser measurement method of the roll on a machine tool, and to confirm an efficiency of the method. The developed system consists of an interferometer and a V-shaped reflector. The interferometer is mainly composed of a corner cube prism, a polarized beam splitter, three quarter wave plates, and a bi-prism. In order to increase the amount of change of the laser path length with respect to the change of the roll, retroreflective prisms are attached to the rear side of the interferometer. The sensitivity and the dispersion of roll measurement data are improved by increasing number of the retroreflection. The developed system and a conventional roll measurement system which uses a long-sized plane mirror are mounted on a machining center, and measurements of the roll are pursued simultaneously. The data obtained by the developed system show the same tendency as method using the long-sized plane mirror. From the results, the availability of the developed system to detect the roll that occurs in a comparatively long travel, about $1 \mathrm{~m}$, is confirmed.
\end{abstract}

Key Words : Laser interferometer, Retroreflection methods, Roll, Machine tool, Optical measurement

\section{1. 緒言}

産業界においては, 製品の高品質化, 高密度化への要求は留まることがない. 特に近年は光学部品, 医療部品, 精密金型等に対応するため，工作機械の高精度化への要求は一層高まりつつある．工作機械の動作精度には，静 的精度と動的精度があることは知られている。前者は，送りネジや動作ユニット案内面の精度，複数の案内面間 の直角度などによって決定する精度であり，非加工時の動作に伴って発生する偏差から求めることができる，後 者は主に加工中の熱や負荷に起因する機械変形によって決まる．精密加工や仕上げ加工を行う場合には切削負荷 が小さいので，機械の動作精度は主に静的精度によって決定すると言っても良い。このため，機械の出荷検査や 検収検査には，静的精度の計測が実施されている。

* 論文 No.13-00828 [DOI: 10.1299/transjsme.2014dsm0055]

${ }^{* 1}$ 正員，金沢大学理工研究域（广920-1192 石川県金沢市角間町）

*2 富士重工業(株)（干181-8577 東京都三鷹市大沢 3-9-6）

*3 石川県工業試験場（广920-8203 石川県金沢市鞍月 2-1）

*4 シグマ光機(株)（广924-0838 石川県白山市八束穂 1-1）

${ }^{* 5}$ 津田駒工業(株) (下921-8650 石川県金沢市野町 5-18-18)

*6 (株) 松浦機械製作所 (广910-8530 福井県福井市漆原町 1-1)

E-mail: gs383554@wa3.so-net.ne.jp 
Nakayabu, Okada, Asakawa, Kanamaru, Hirosaki, Tamura, Yachi, Shimizu, Kawara and Amaya, Transactions of the JSME (in Japanese), Vol.80, No.811 (2014)

レーザ測長機は工作機械の運動に伴って発生する位置決め精度, 運動の真直度, 角度偏差等を高精度測定でき る装置として広く普及している．移動体に発生するこれらの偏差は，移動体と案内体との間の相対変位として検 出するよう工業規格で規定されている．例えばサドル移動立て形マシニングセンタのテーブル送りに伴って発生 するピッチやヨーをレーザ測定するときは，反射鏡をテーブル上に，干渉計はテーブルの案内体であるサドル上 に固定するよう規定している，レーザ測長機が普及した背景には，高精度測定が可能であるという特徵の他に， 干渉計と反射鏡との間の相対変位を検出できる装置であることが大きな要因となっていると思われる．しかし， 現在でもロールについては実用的な干渉計と反射鏡が開発されていないため, テーブルと主軸ヘッドに発生する 角度偏差の各々を精密水準器で測定し，その差からロールを演算するよう規定している(JISB6336-2, 2002). 2台の 水準器を用い，かつ計算を伴うこの測定法はやや煩雑であり，ロール測定専用のレーザ干渉計と反射鏡の開発が 待たれるところである.

他の測定法としては，移動体の移動長さに等しい長尺平面鏡を用いてレーザ測定する方法がある(Agilent Technologies, 2009)，長尺平面鏡は長くなるほど製作が難しく取り扱いも容易でないため，移動距離の長い測定は 困難である.また，ロールに比例して傾斜する懸垂平面鏡からの反射レーザ光を利用してロールを求める方法(谷 村, 加藤，1987)があるが，テーブルやコラムなどの移動に伴う重心移動によって機械全体が倒れるため, 移動体 と案内体との間の相対角度偏差として発生する真のロールを測定できない可能性がある．更に，鉛直移動体に発 生するロールについては㲘垂平面鏡や水準器を使用できないため, 直定規, 円筒スコヤ，ダイヤルゲージなどを 用いて測定しなければないのが現状である。これらの他に，二つの 4 分割フォトダイオードの出力と，これら二 つのダイオードの設置間隔からロールを演算する試みも早くからある(今井, 清水, 2001)(K.C.Fan, et al., 1998)が, 工作機械の精度測定用としては分解能が不足していることなどのため，まだ実用化に至っていない．

著者らは過去に，二重光路干渉計(Okaji and Imai, 1985)(岡路, 1996)の原理に基づき，鉛直移動体に発生するロー ルもレーザ測定可能な干渉計と反射鏡を提案し，その有用性を明らかにした(中藪他, 1986)(中藪他, 1995)(中藪他, 2002)(中藪他, 2009). 本研究は, 過去に提案した装置のサイズを維持しつつ, 干渉計背面に再帰反射プリズムを 付加して干渉計と反射鏡との間のレーザ往復回数を増加させ，光路長変化量の増大を図って感度向上を図ったも のである．また，長尺平面鏡を用いて計測する従来の方法との比較のため，本開発装置と長尺平面鏡をマシニン グセンタに実装し，ロールの同時測定を試みた。その結果，開発装置の有用性を確認できたので報告する.

\section{2. 測定装置の構成と動作原理}

開発した測定装置の動作原理を図1で説明する。干渉計はコーナキューブプリズムCCP $\mathrm{C}_{1}$, バイプリズム $\mathrm{BP}, 1 / 4$ 波長板 $\mathrm{QP}_{1}, \mathrm{QP}_{2}, \mathrm{QP}_{3}$, 偏光ビームスプリッタ $\mathrm{PBS}$, ターニングミラーTMで構成される.レーザヘッドLHからは, 水平直線偏光のP波（実線で示す）と上下直線偏光のS波（破線で示す）が照射されるが，ここではP波に着目し， その経路について述べる.PBSの右側へ入射したP波は，分光面で上側へ向けて反射する．次にTMで水平に反射

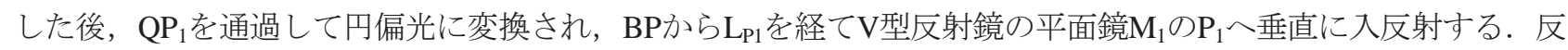
射したP波は，再度 $\mathrm{QP}_{1}$ を通過することにより円偏光から上下直線偏光に変換される．このことにより，P波はTM

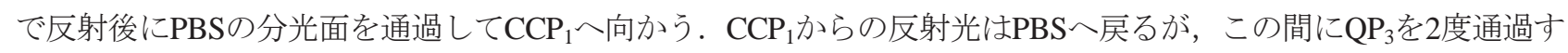
るため, 再び水平直線偏光に変換されている. このためPBSの分光面で水平方向に反射しBPへ向かう. $\mathrm{CCP}_{1} へ の$ 入射光と反射光の位置関係は， $\mathrm{CCP}_{1}$ の中心に対して点対称であるから， $\mathrm{P}$ 波はBPの左側を通過することになり， $\mathrm{L}_{\mathrm{P} 2}$ を経て平面鏡 $\mathrm{M}_{2} の \mathrm{P}_{2}$ へ垂直に入反射して $\mathrm{PBS}$ 戻る. この間に $\mathrm{QP}_{2}$ を2度通過することにより再び上下直線偏光 に変換されるため, PBSの分光面を通過してレーザヘッド側の光電変換器 $\mathrm{OE}$ 入射する. 上下直線偏光として干 渉計一入射する $\mathrm{S}$ 波も, 同様な偏光の変化により $\mathrm{L}_{\mathrm{S} 1}, \mathrm{~L}_{\mathrm{S} 2}$ を辿り, $\mathrm{S}_{1}, \mathrm{~S}_{2}$ での入反射を経て, 光電変換器 $\mathrm{OE} 入 入$ 射 寸る. $\mathrm{W}_{1}, \mathrm{~W}_{2}$ はP波と $\mathrm{S}$ 波の平行度調整用偏向子であり，これらの偏向子を回転調整することにより，PBSの形状 精度やターニングミラーの接着精度に関係なく, V型平面反射鏡に向かうP波とS 波が平行になるよう調節した。 $\mathrm{V}$ 型反射鏡に図示方向のロール $\gamma$ が発生すると, $\mathrm{P}_{1}, \mathrm{P}_{2}$ はV 型反射鏡の山側へ移動し， $\mathrm{S}_{1}, \mathrm{~S}_{2}$ は谷側へ移動する。こ のことによってP波の光路が短くなり, $\mathrm{S}$ 波の光路が長くなって両波の光路長に差が発生するので, ロール検出が 可能となる. 図1のX, Y, Z方向に発生する位置偏差と，X, Y 軸周りに発生する角度偏差 $\alpha, \beta$ 対しては光路長 差が発生しないので本開発装置は感度を持たない，干渉計から反射鏡へ向かう 2 光波の挟角を $2 \varphi$, 上下間隔を $2 b$ 


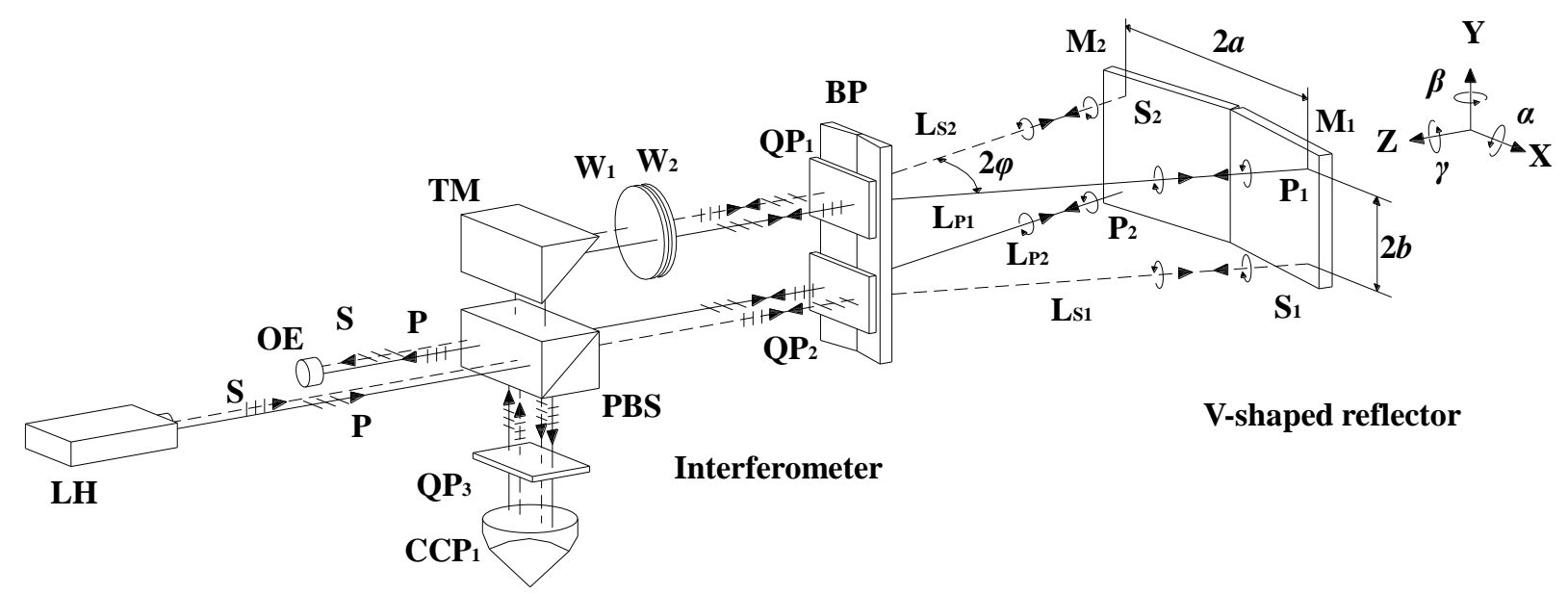

Fig.1 Optical path layout of the developed roll measurement system. To ensure the parallelism between $\mathrm{S}$ and $\mathrm{P}$ is important. $\mathrm{L}_{\mathrm{S} 1}$ and $\mathrm{L}_{\mathrm{P} 1}$ become parallel with rotational adjustment of wedge prism $\mathrm{W}_{1}$ and $\mathrm{W}_{2}$, then $\mathrm{L}_{\mathrm{P} 2}$ and $\mathrm{L}_{\mathrm{S} 2}$ become also in parallel automatically. Relationship between $\gamma, \varphi, b$ and output of laser measurement system $\Delta$ is expressed by equation (1). Changes in $a$ does not affect the sensitivity. The system is designed that has measurable length up to $1.1 \mathrm{~m}$.

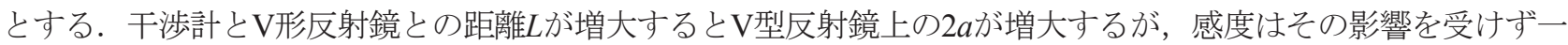
定であることを前報(中藪他, 1986)(中藪他, 1995)(中藪他, 2002)(中藪他, 2009)で確認している. 図1に示す反射鏡上 の反射点が4点の場合，レーザ測長機表示長さ $\Delta_{4}$ とロール $\gamma$ の関係は，式(1)で表せる(岡路, 1996). 本研究では，再 帰反射を応用し，反射鏡上の反射点数を4点から 8 点，12点，16点に増やし，レーザ測長機表示長さ $\Delta_{i}(i=4,8,12,16$ は反射点数）を増大させて感度の向上を試みた。この干渉計と反射鏡の測定感度 $C=\Delta_{i} / \gamma$ を校正作業によって子め 求めておけば，発生する任意の $\Delta_{i}$ に対するロール $\gamma$ は， $\triangle_{i}$ をで除すことによって求められる．なお，V型反射鏡 のi点ヘレーザが入反射する方法をi点反射法と呼ぶことにする.

$$
\gamma=\Delta_{4} /(4 b \sin \varphi)
$$

図 2 は開発した干渉計と V 型反射鏡を，図 3 は後述の再帰反射プリズムを取り付けた干渉計後部を示す.

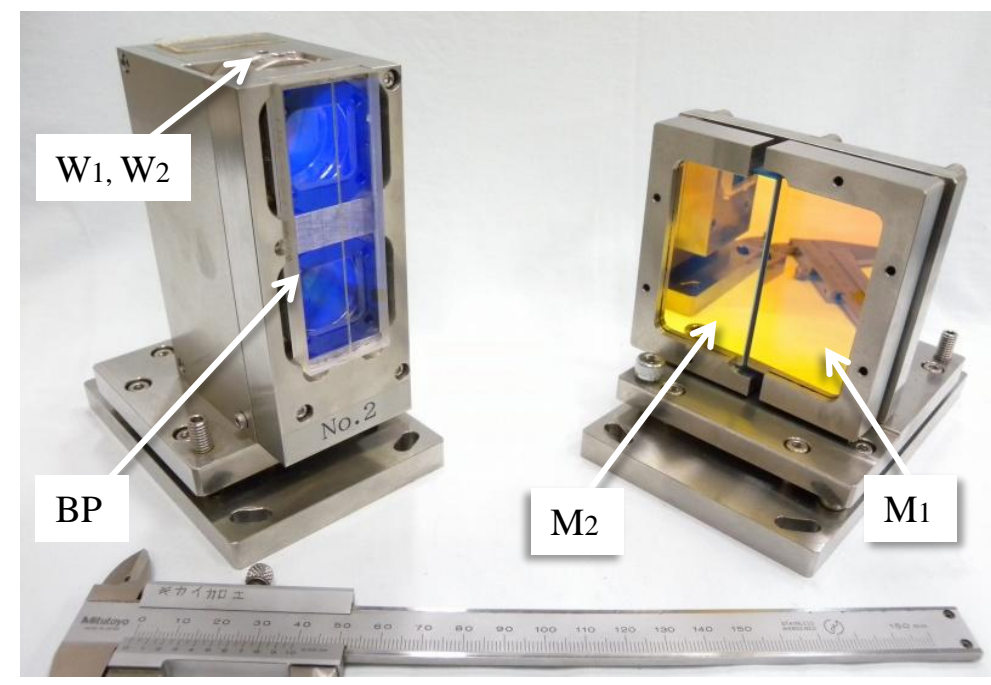

Fig.2 Developed interferometer (left) and V-shaped reflector (right)

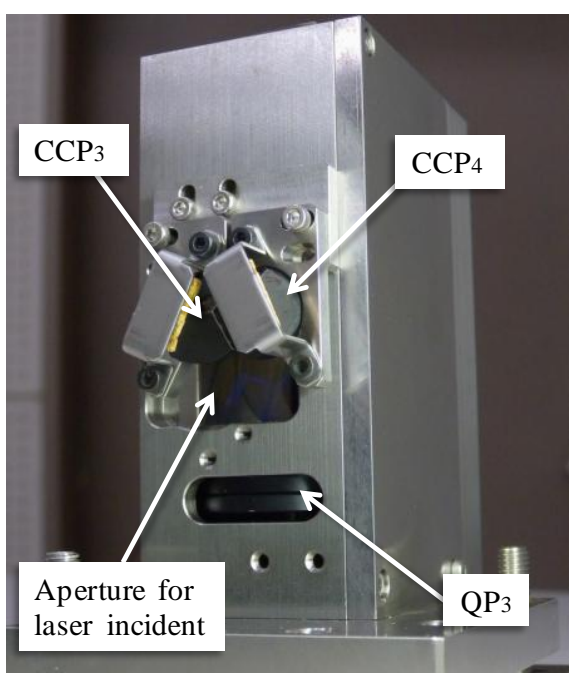

Fig.3 Rearview of the interferometer 


\section{3. 多点反射による測定感度の向上}

\section{$3 \cdot 1$ 測定感度の評価}

図4は，感度測定を行った光学ベンチ上の機器配置の平面図で，LHはレーザヘッド，RIは開発したロール測定 用干渉計， RRは同じくロール測定用V型反射鏡を示す. 移動ステージは， RRとRIの距離 $L$ を段階的に変化させ， Lが開発装置の感度に影響しないことを確認するためのものである．移動ステージ上には，Z軸回りにロール

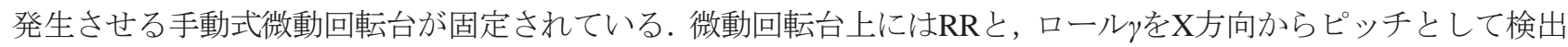
するためのピッチ測定用反射鏡PRが固定されている．ピッチ測定用の干渉計PIは移動ステージ上に固定されてい る。PRは2個のコーナキューブプリズムCCPで構成されている．ピッチ角 $\gamma$ は，2個のCCP間の上下間隔 $l$ とーザ 測長機表示長さdから式(2)のように求められる。 HMはハーフミラー，TMはターニングミラーを示す。ロールと ピッチの各干渉光は光電変換器 $\mathrm{OE}_{\mathrm{R}}, \mathrm{OE}_{\mathrm{P}}$ で受光した.

$$
\gamma=\sin ^{-1}(d / l)
$$

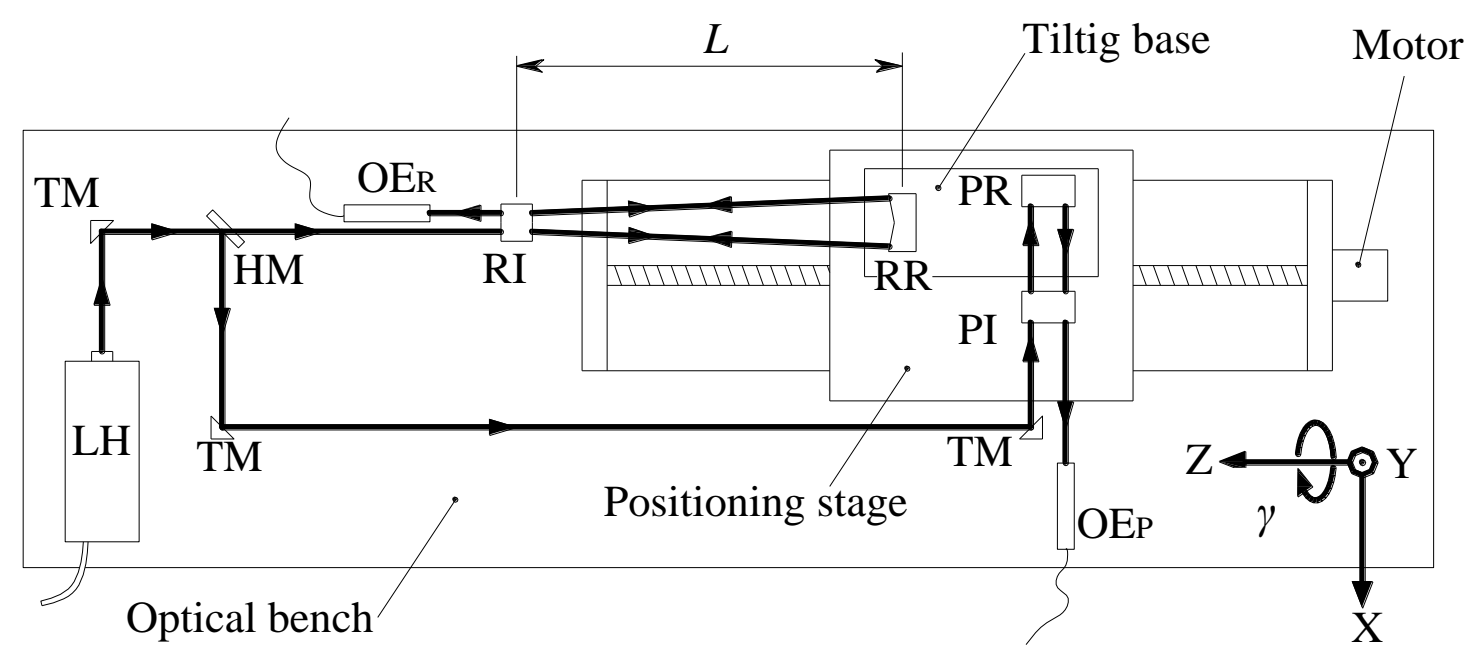

Fig.4 Arrangement of the system for sensitivity measurement. Output $\Delta$ from laser measurement system with roll $\gamma$ generated by tilting base is measured by developed RR and RI. On the other hand, $\gamma$ is measured as pitch by already established method by PR and PI. Sensitivity $\Delta / \gamma$ is obtained from both of the data.

\section{$3 \cdot 2$ 測定感度と測定分解能の向上}

レーザ測長機の分解能を $m$ とすると，レーザ測長機表示長さ $\Delta_{i}(i=4,8,12,16) \quad$ は $n_{i}(i=4,8,12,16)$ を係数として式 (3)のように表現できる.

$$
\triangle_{i}=n_{i} m
$$

また， $\Delta_{4}$ と再帰反射数に比例して増大する $\Delta_{i}$ との関係は式(4)で表現できる.

$$
\Delta_{i}=(i / 4) \Delta_{4}
$$

式(3)と式(4)を，式(1)へ代入して式(5)が得られる.

$$
\gamma=n_{i} m /(i b \sin \varphi)
$$


Nakayabu, Okada, Asakawa, Kanamaru, Hirosaki, Tamura, Yachi, Shimizu, Kawara and Amaya, Transactions of the JSME (in Japanese), Vol.80, No.811 (2014)

ロール $\gamma$ は $n_{i}$ 個のmに対応して発生するから，ロールの測定分解能 $\gamma / n_{i}$ は式(5)を変形した式(6)で表される.

$$
\gamma / n_{i}=m /(i b \sin \varphi)
$$

式(6)から，ロールの測定分解能 $\gamma / n_{i}$ を向上させるには高分解能のレーザ測長機を採用して $m$ 小さくするか, 再帰反射によってiを大きくすればよいことになる.

本研究で用いたレーザ測長機はHP社製5526Aで, 分解能は比較的小さく $264(0.01 \mu \mathrm{m})$ である.このレーザ測長機 を4点反射法に用いた場合のロール測定感度と測定分解能は高いとは言えない. ロール測定分解能の向上を目的に, 図3のように再帰反射プリズムを干渉計背面に固定し, V型反射鏡上の反射点数を増加させて $\triangle_{i}$ を増大させること を試みた．図5は8点反射，図6は12点反射，図7は16点反射の各光路と各再帰反射プリズムを示寸．

例えば，図5のように干渉計から光電変換器 $\mathrm{OE}$ 戻万うとする干渉光を $\mathrm{CCP} 2$ によって再び干渉計へ入射させ, 当初の光路を逆に辿らせれば，反射鏡上の合計反射点数を4点から8点に倍増できる. 本研究では，図6のように 2 個の再帰反射プリズムCCP3，CCP4によって反射点数を 12 点に，図7のように 2 個の再帰反射プリズムCCP5, CCP6 によって反射点数を16点にすることにより, レーザ光路長の変化量増大による感度向上を試みた.

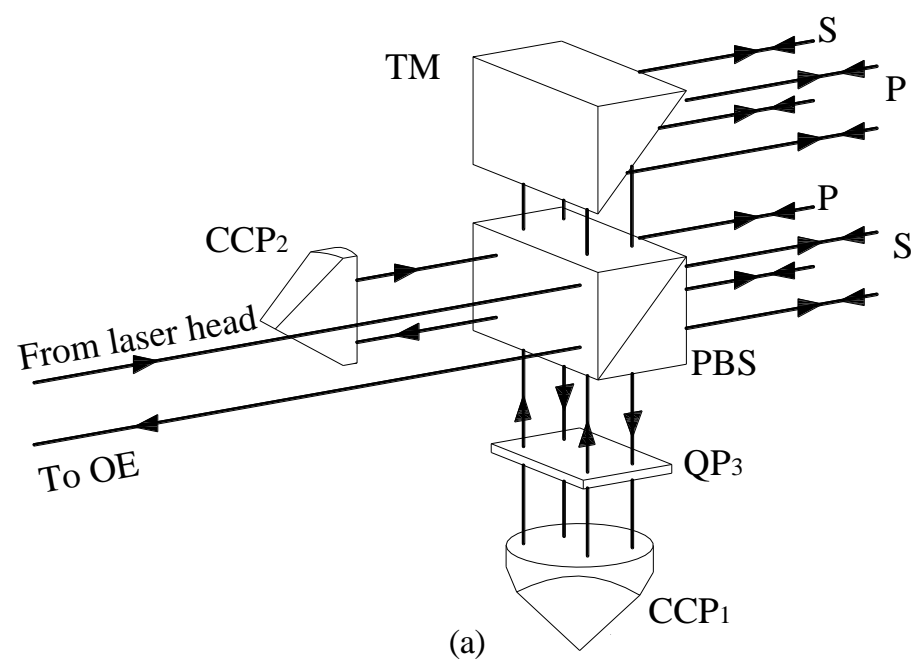

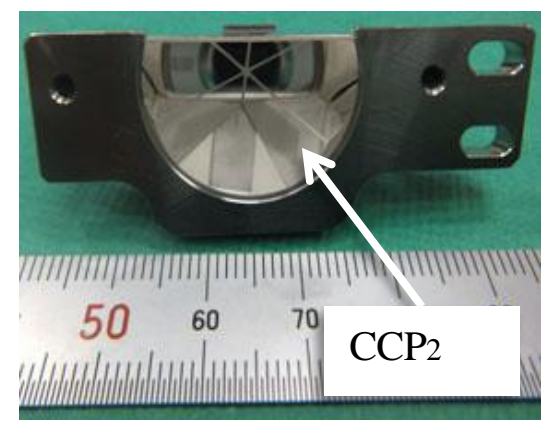

(b)

Fig.5 (a) Optical layout of 8 points reflection and (b) attached corner cube prism on the interferometer

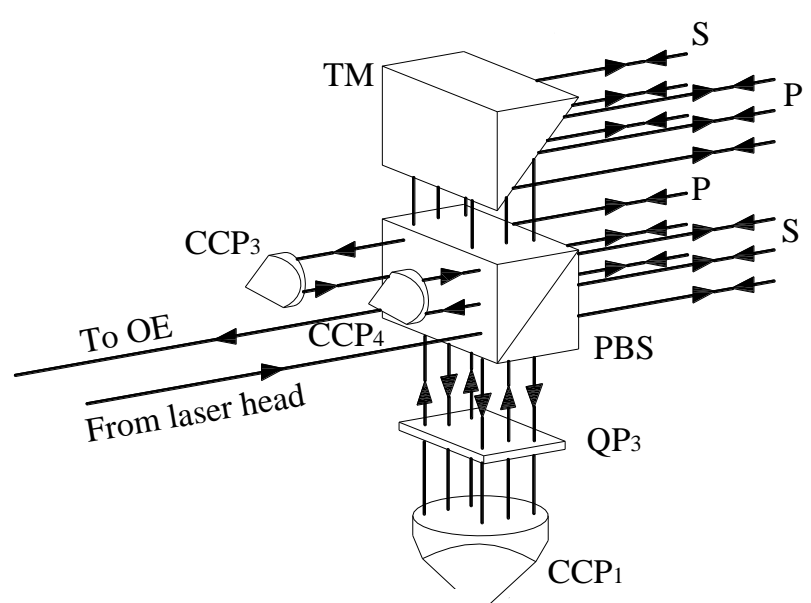

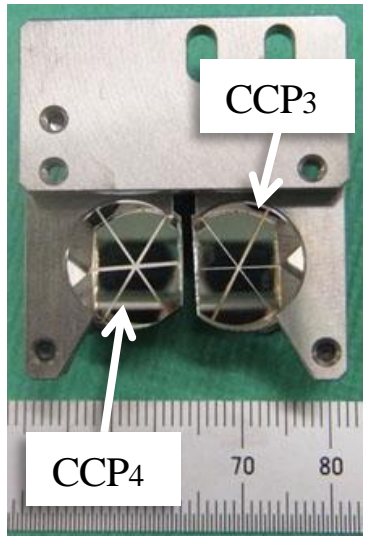

(b)

(a)

Fig.6 (a) Optical layout of 12 points reflection and (b) attached corner cube prisms on the interferometer 


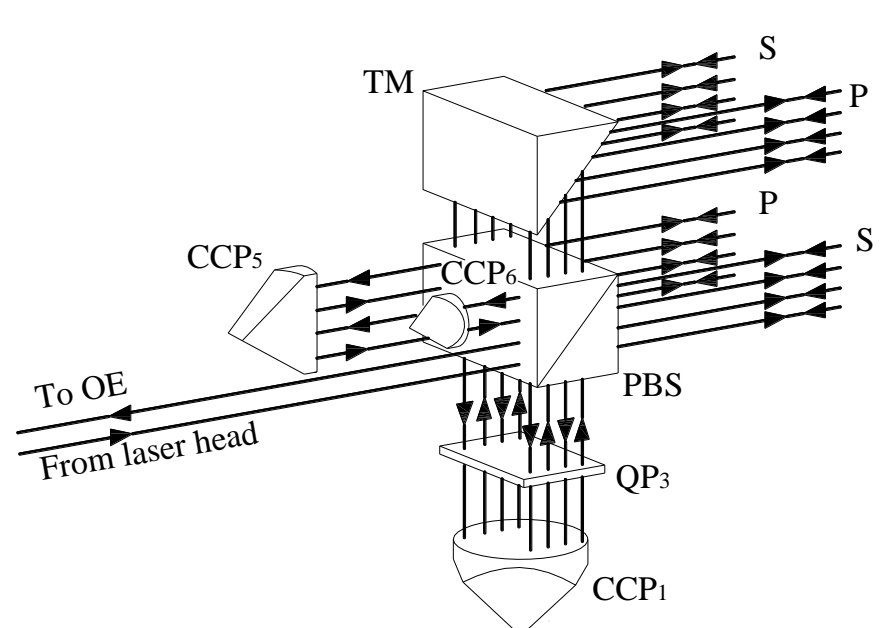

(a)

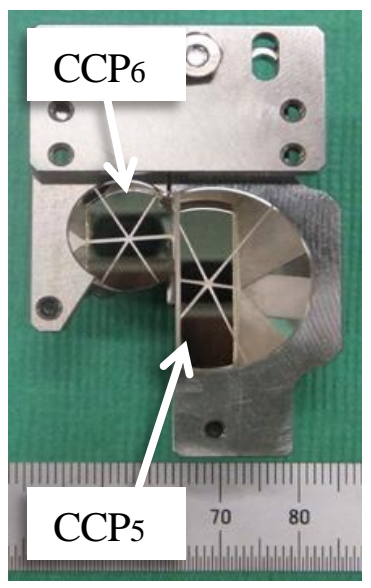

(b)

Fig.7 (a) Optical layout of 16 points reflection and (b) attached corner cube prisms on the interferometer

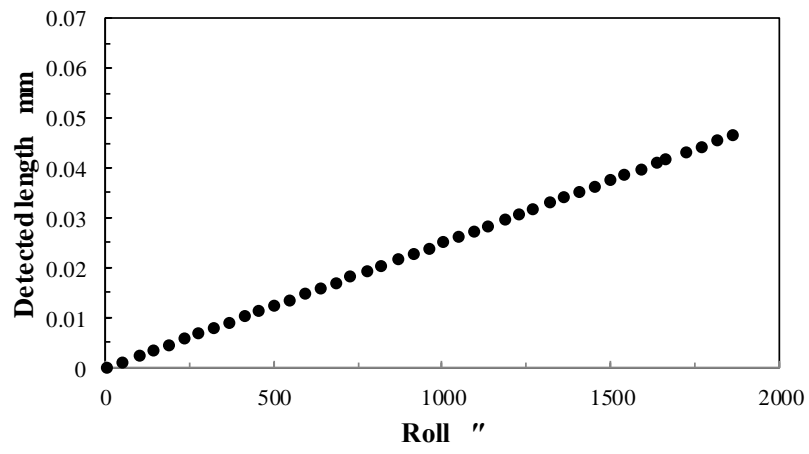

(a) $L=500 \mathrm{~mm}$

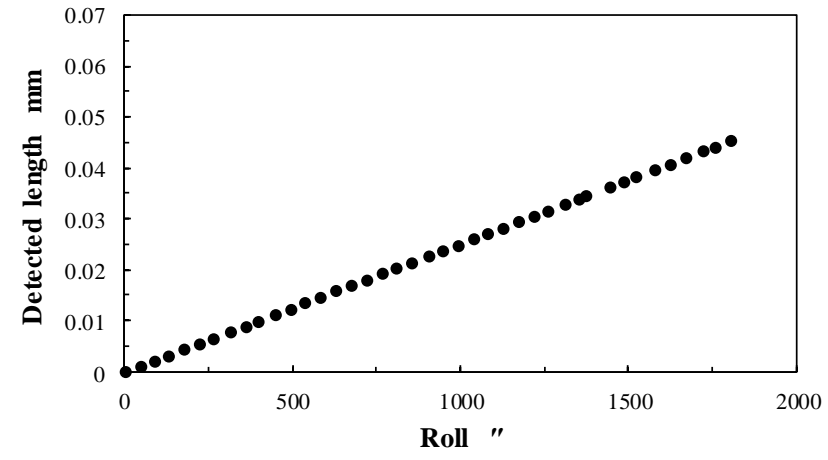

(b) $L=800 \mathrm{~mm}$

Fig.8 Relation between measuring distance $L$ and sensitivity in case of 12 points. The value $a$ increases according to the distance $L$ between the interferometer and the reflecter. The figures show that the magnitude of $a$ does not affect the sensitivity.

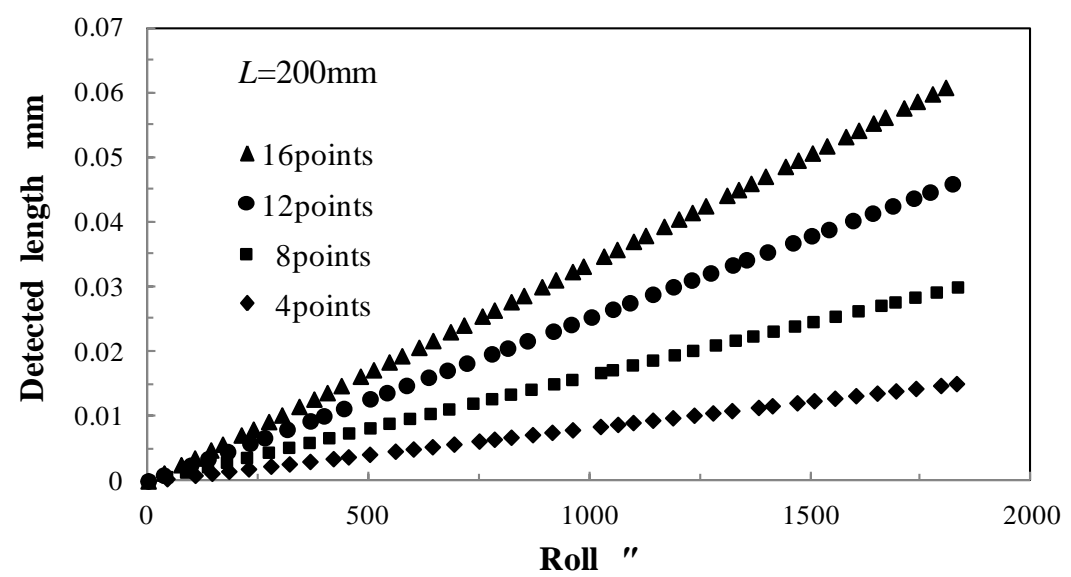

Fig.9 Relationship between the sensitivity and number of reflecting points on V-shaped reflector. The figure shows that the number of reflection points on the reflector is proportional to the sensitivity. 
図8は，測定長さ $L$ が測定感度に影響しないことを確認したデータである．感度 $C=\Delta_{i} / \gamma$ は各データ分布の回帰 直線の傾きから求められるが, $L=500 \mathrm{~mm}$ と $L=800 \mathrm{~mm}$ では感度に変化がないことがわかる.

各反射点数法のロール検出感度も, 4 点反射法と同様に図 4 に示寸方法で求めた. 感度は干渉計と反射鏡の距離 $L$ に影響されないことから，Lを一定值 $200 \mathrm{~mm}$ とし, 反射点数を 4 点, 8 点, 12 点, 16 点に変化させた. 得られた口 ール ととレーザ測長機表示長さ $\triangle_{i}$ の関係を図9に示す.

図9から，反射点数の増加に比例して回帰直線の傾きが大きくなり，感度が向上することが分かる. 図10(a), (b) は, 回帰直線とサンプリングデータとの偏差を，12点反射法と16点反射法を例にして示したものであり, 反射点数 が大きいほど偏差が小さくなることが分かる.表1は以上の結果をまとめたものであり, 反射点数に比例して感度 が向上し，回帰直線に対するデータ偏差の標準偏差が減少することを示している.

表1の右欄に, 本実験で使用したレーザ測長機の分解能から得られるロール測定の分解能を記す. 本実験に用い たレーザ測長機の分解能は比較的低いが，高い分解能を持つレーザ測長機で測定すれば，ロールの測定分解能は 式(6)で示したように更に向上すると言える.

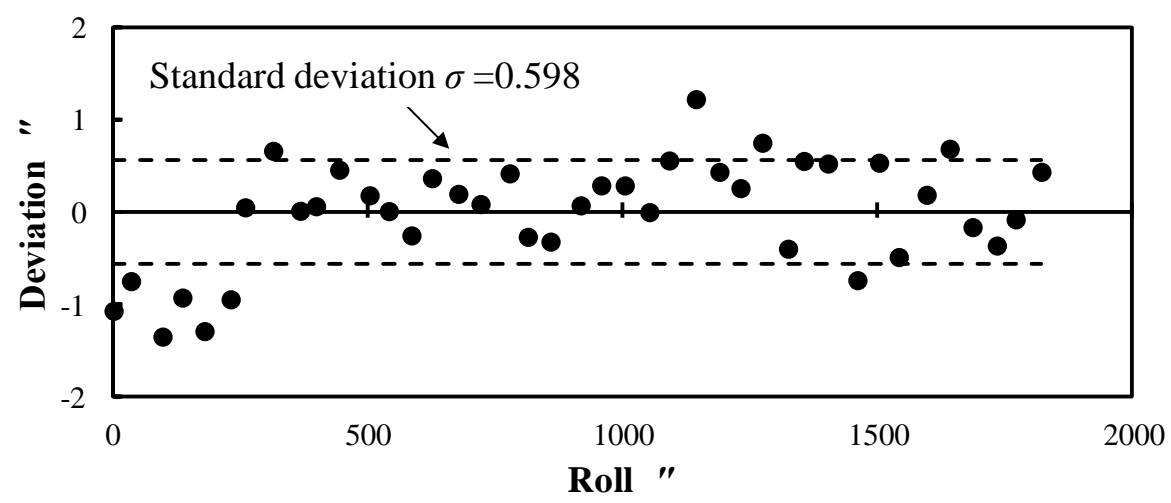

(a) 12points reflections

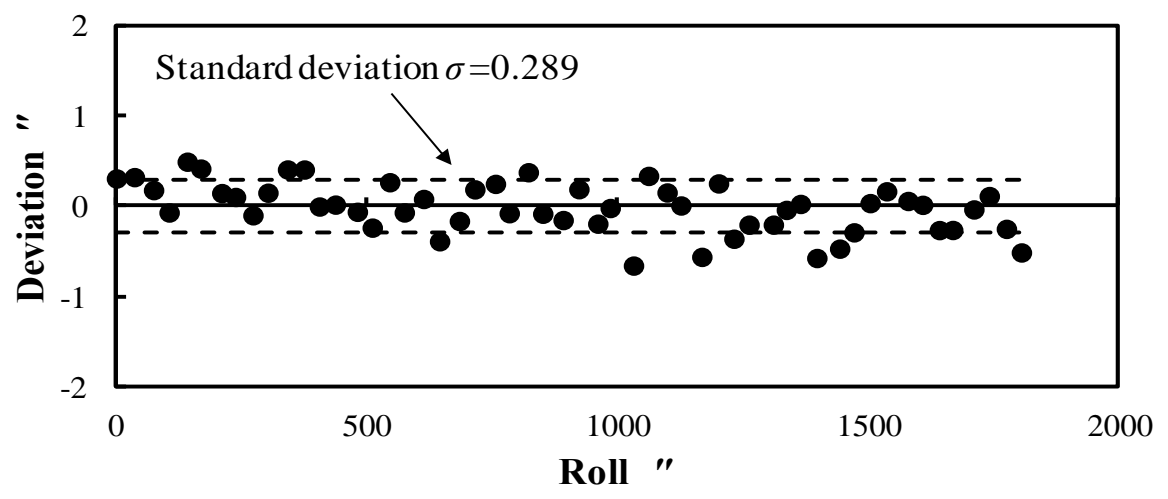

(b) 16points reflections

Fig.10 Relation between data variance and number of reflecting points on V-shaped reflector. The figure shows that as the number of retroreflective increases, the deviation from the regression line of the data is reduced and the reliability of the data is improved. 
Nakayabu, Okada, Asakawa, Kanamaru, Hirosaki, Tamura, Yachi, Shimizu, Kawara and Amaya,

Transactions of the JSME (in Japanese), Vol.80, No.811 (2014)

Table1 Relation between reflection points and characteristics. The resolutions of the right-most column are in case of the laser measurement system, with $0.01 \mu \mathrm{m}$ resolution, used in the study.

\begin{tabular}{|c|c|c|c|}
\hline $\begin{array}{c}\text { Number of } \\
\text { Reflection } \\
\text { points }\end{array}$ & $\begin{array}{c}\text { Sensitivity } \\
\left(\mathbf{\times} \mathbf{1 0}^{-\mathbf{5}} \mathbf{m m} / \mathbf{}^{\prime \prime}\right)\end{array}$ & $\begin{array}{c}\text { Standard } \\
\text { deviation } \\
\left(\mathbf{( " )}^{\prime}\right)\end{array}$ & $\begin{array}{c}\text { Resolution } \\
(\text { ") }\end{array}$ \\
\hline 4 & 0.822 & 2.481 & 1.22 \\
\hline 8 & 1.643 & 1.437 & 0.61 \\
\hline 12 & 2.510 & 0.598 & 0.40 \\
\hline 16 & 3.369 & 0.289 & 0.30 \\
\hline
\end{tabular}

しかし，再帰反射を応用して感度向上を図る本研究の方法には，反射点数を増や寸に連れて測定可能なロール 変動幅が減少するという短所があることも分かった，この原因は，反射鏡にピッチ，ヨー，ロールの角度偏差が 発生すると，反射鏡上で反射するレーザ光の方向が変化し，発生する角度偏差が大きい場合には反射レーザ光が 光電変換器の受光空(外径 $10 \mathrm{~mm}$ )から逸れてしまうことにある. 受光空からのレーザ光の逸れ量は, 反射鏡に発生 する角度偏差が同一でも，測定距離が長くなるほど，また再帰反射数が多いほど大きくなるため，測定可能な口 一ル変動幅は小さくなる．例えば，図8，図9は，4点反射法では10000"を超えるロール変動幅でデータ収集可能で あったにもかかわらず，上記現象によって，16点反射法の収集可能ロール変動幅が約1900"となったため，横軸最 大值を2000"に限って表示したものである. よって, 工作機械テーブルなど移動長さの大きい物体のロール測定に おいては, 一般のレーザ測定よりも慎重なレーザアライメント調整が必要であり, 場合によっては再帰反射数を 多くできないことが分かった.

\section{4. マシニングセンタに発生するロールの測定}

\section{$4 \cdot 1$ 長尺平面鏡による測定方法との比較測定}

開発した装置を用い，テーブル移動立形マシニングセンタのテーブル送り $800 \mathrm{~mm}$ に伴って発生するロールを測 定した．今回は，開発装置の評価を行うため，長尺平面鏡を用いるロール測定法を同時に実施し，両測定結果を 対比して評価した.

テーブル移動長さが大きいため，16点反射法では，光電変換器の受光調整が困難だったので，12点反射法を採 用した. ロールは, 得られたレーザ測長機表示長さ $\Delta_{12}$ を表 1 に示寸 12 点反射法の感度 $C=2.510 \times 10^{-5} \mathrm{~mm} /{ }^{\prime \prime}$ で除して 求めた。

他方, 長尺平面鏡によるロール測定は，ロールを移動軸に直角の方向からピッチとして測定するものであり,式 (2)に従い，レーザ測長機表示長さdをP波とS波の上下間距離にで除してロールを求めた.

図11に, 採用した長尺平面鏡 $(60 \times 500 \mathrm{~mm})$ を示す. 図12にマシニングセンタ上に固定した装置の構成を示す. 両測定の反射鏡は共にマシニングセンタテーブル上に固定し，各干渉計，ビームスプリッタBS，ターニングミラ 一 $\mathrm{TM}$, 光電変換器 $\mathrm{OE}_{\mathrm{R}}, \mathrm{OE}_{\mathrm{P}}$ 等は，主軸頭に固定した板状のベースに固定配置した，測定には，感度校正に用い たHP製5526Aを使用し，ヘッドから出射したレーザ光をビームスプリッタBSで2本に分光し，各測定系へ照射し た. 各ロール測定装置から得られる干渉光は, 各々別の外部光電変換器 $\mathrm{OE}_{\mathrm{R}}, \mathrm{OE}_{\mathrm{P}}$ で受光してロールに換算した. 図13に実際の測定風景を示寸.

測定は，テーブルの全移動長 $800 \mathrm{~mm} に つ い て ， 10 \mathrm{~mm}$ 送る毎に10sのドエルを設け，ドエル中のデータをパソコ ンで自動読み取りした，開発したロール測定装置は移動長さ0 1100mmでロール測定が可能であるが，長尺平面 鏡の長さが500mmであるため, 両装置の比較測定は送り量0 490mmの区間で行った. 図14にその結果を示す. 図 15は，テーブルの全移動長 $800 \mathrm{~mm} の$ 往路と復路に発生するロールを，開発装置のみで検出したものである. 
Nakayabu, Okada, Asakawa, Kanamaru, Hirosaki, Tamura, Yachi, Shimizu, Kawara and Amaya,

Transactions of the JSME (in Japanese), Vol.80, No.811 (2014)

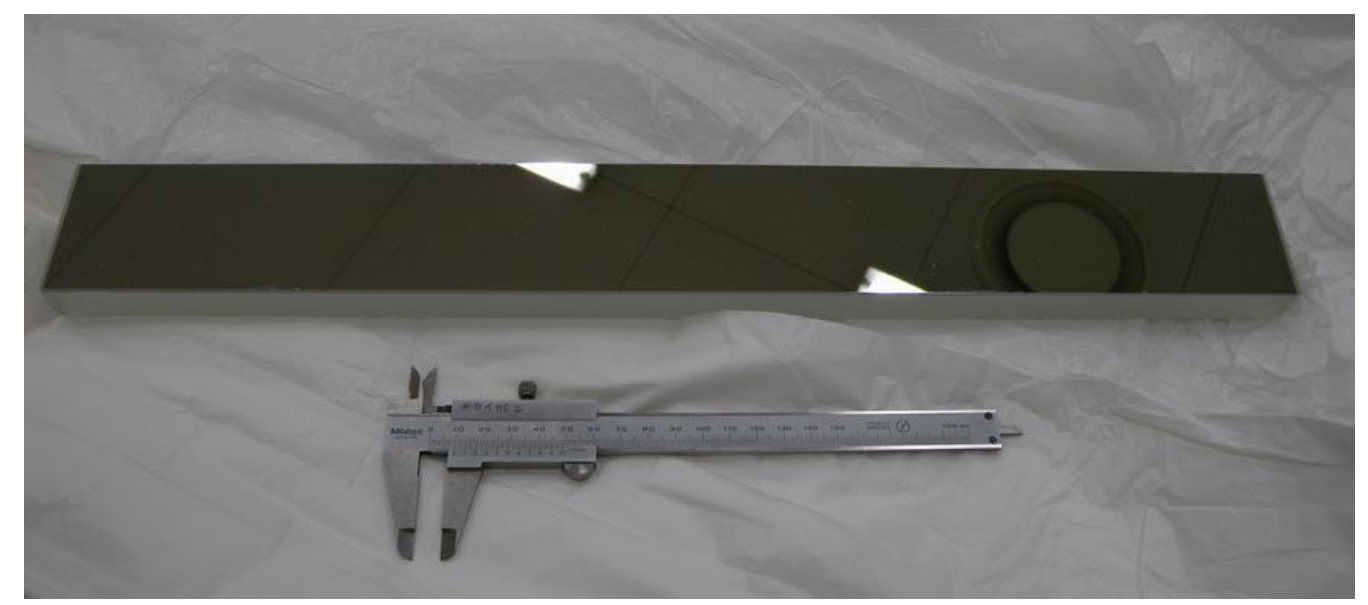

Fig.11 The long-sized plane mirror used for comparative measurements of roll

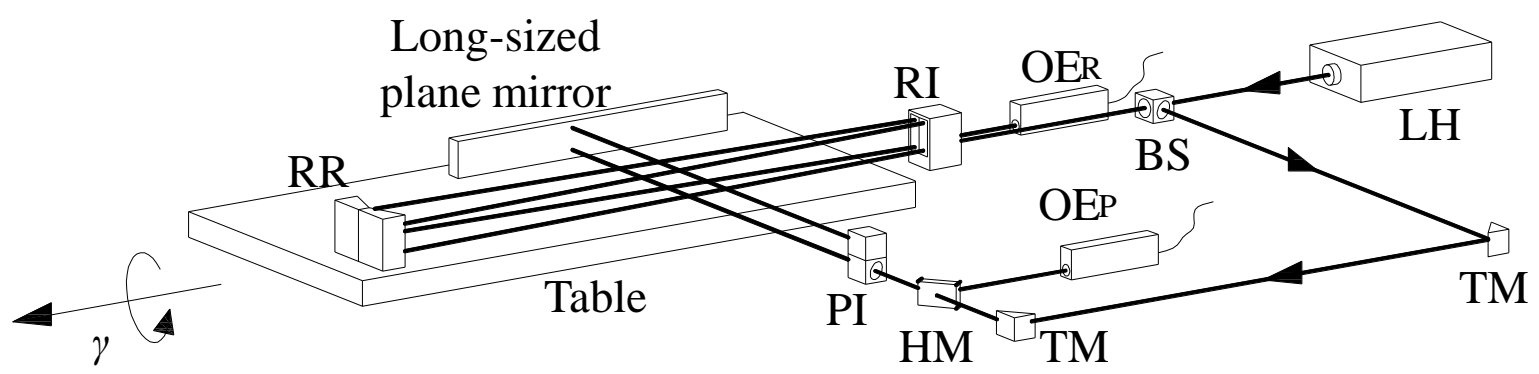

Fig.12 The comparative experiment arrangement of the developed method and the long-sized plane mirror method. RR and the long-sized plane mirror are fixed on the table. Others are fixed on the spindle head.

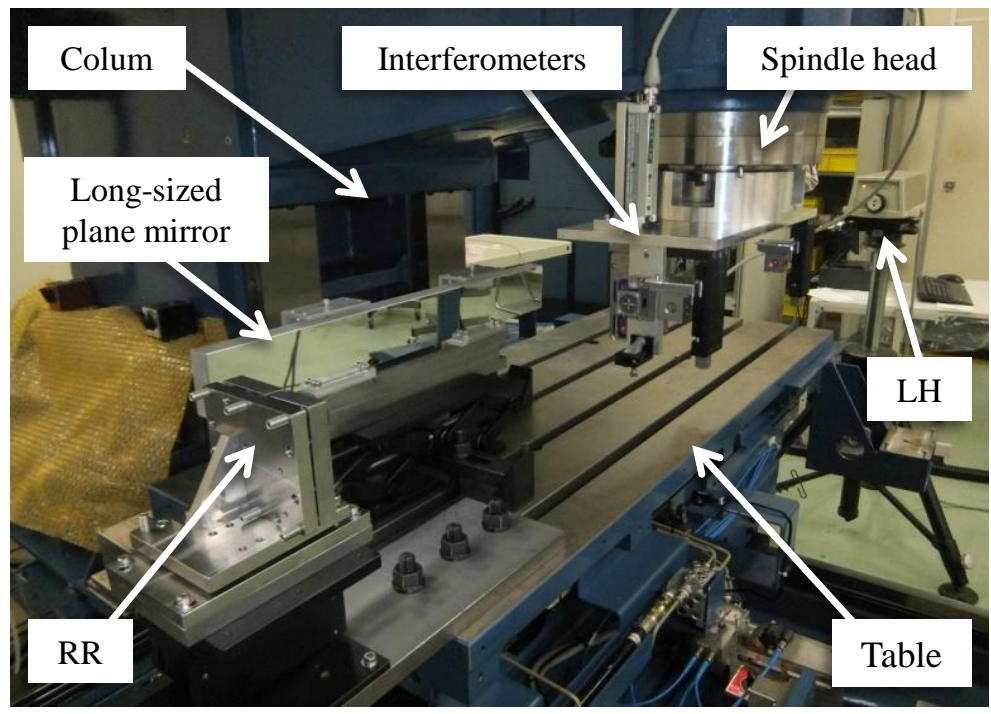

Fig13 The long-sized plane mirror and the V-shaped reflector (RR) on a machining center 
Nakayabu, Okada, Asakawa, Kanamaru, Hirosaki, Tamura, Yachi, Shimizu, Kawara and Amaya,

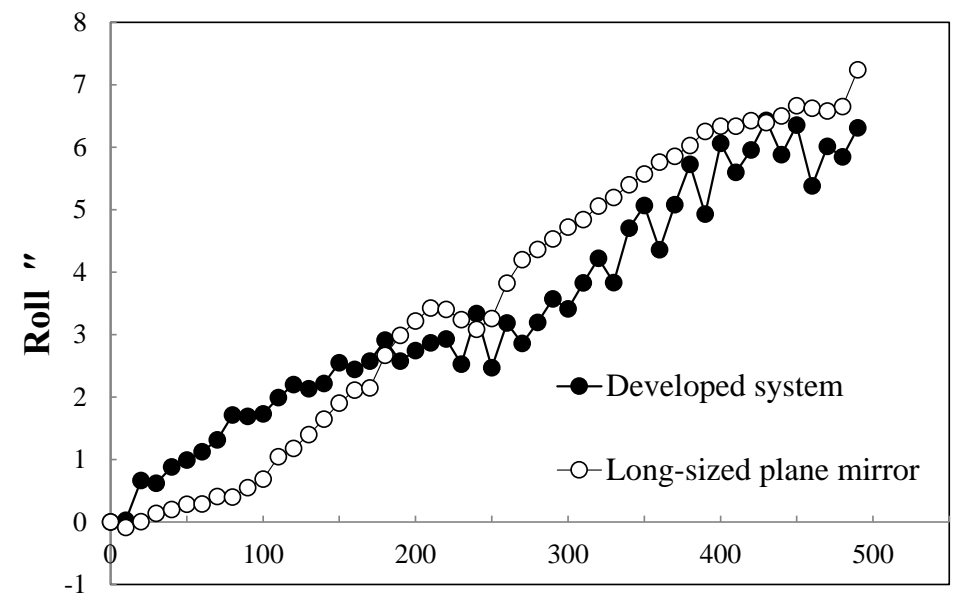

Feed mm

Fig.14 Comparison of the developed system and long-sized plane mirror method. Since both data show similar results, the usefulness of the developed system is confirmed. The deviation between the two data is possibly owing to the flatness of both plane mirrors.

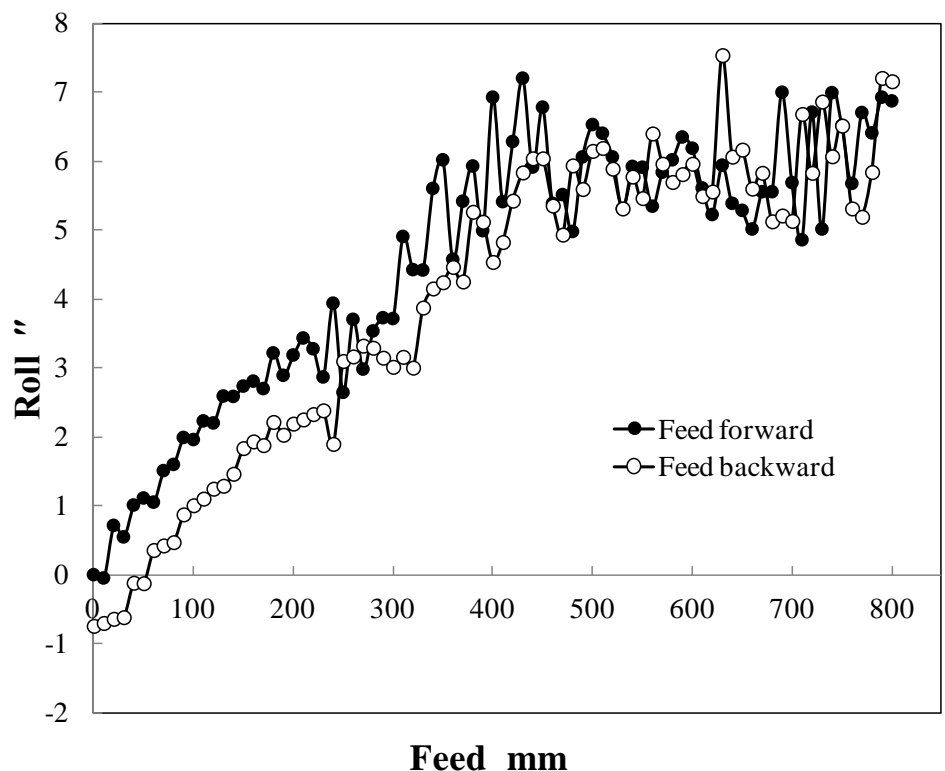

Fig.15 Comparison of feed forward and feed backward by the developed system. The increase of data variation with increase of measured distance are probably related mainly to air fluctuation.

\section{$4 \cdot 2$ 結果と考察}

図14から，両装置から得られるロール測定值は，共に送り量の増大に伴って正方向に増大しており,テーブル案 内面が僅かに一方向に捻じれていることが分かる. 両データの間には，送り量の増大に伴って約 1 のの偏差が発生 しているが，この偏差は，レーザの反射位置が僅かに凹凸のある平面鏡上を移動するため，両平面鏡の平面度の 違いが原因となっていると考えられる．特に，長尺平面鏡上の反射点は，テーブル移動長に等しい距離を移動す るので，鏡の平面度がデータに直接影響していると考えられる：二つの測定值間の偏差が，V型反射鏡と長尺平 
Nakayabu, Okada, Asakawa, Kanamaru, Hirosaki, Tamura, Yachi, Shimizu, Kawara and Amaya, Transactions of the JSME (in Japanese), Vol.80, No.811 (2014)

面鏡のどちらに起因寸るのかを本研究では明確にできなかったが，送りに伴って発生するロールの傾向が同一で あり，両者の偏差も約1"に収まっていることから本開発装置によるロール測定は有効な方法と言える.

図15から,テーブル案内面が全長にわたって僅かに一方向に捻じれていることが窅える.ロール最大值は約7" /800mmであるが，JIS規格(JISB6336-2, 2002) のロール規定值12"/1000mmから，本実験で用いたマシニングセンタ

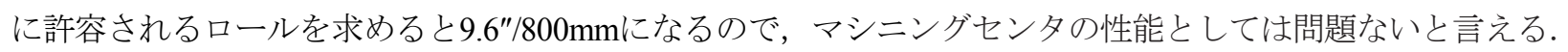

図14，15では，送り量の増大に伴って，データのばらつきが大きくなっている．特に，長尺平面鏡よりも本開 発装置のばらつきが大きい，この原因として，長尺平面鏡はテーブル中央に固定できるが，V型反射鏡はテーブ ルの端部に固定せざるを得ず，送り量が増大するに連れてテーブル端部がテーブル案内からオーバーハング状態 になるため，機械振動がデータに混入している可能性があると考えられる. また，長尺平面鏡の場合は干渉計と 鏡の距離が絶えず短距離で，かつ一定であるのに対して，本研究開発装置の場合は測定距離が増大するに連れて 干渉計とV型反射鏡の距離が大きくなり，かつP波とS波の間隔が挟角 $2 \varphi$ に比例して大きくなる．そのため，各光 波の通過光路の間隔が測定距離に比例して大きくなるため, 各光波に対する空気摇らぎの差が増大し, 測長量が変 動したと考えられる.

現在，広く普及しているロール測定法は長尺平面鏡を用いる方法である.しかし，長い平面鏡の取り扱いは不 便で，製作も困難であることから，移動量が $1 \mathrm{~m}$ に近い移動体に発生するロールのレーザ測定は殆ど実施されて いない，以上の結果から，本装置は，移動量が約 $1 \mathrm{~m}$ の中型のマシニングセンタに発生するロール測定装置とし ては十分な機能を持っていると言える.

\section{5. 結}

工作機械のテーブルなどの移動ユニットに発生するロールを，レーザ測長機で測定できる干渉計と反射鏡を開 発し, 以下の結果を得た.

（1）再帰反射を利用し，ロールを高精度に測定できる干渉計と反射鏡を製作した.

(2) 開発した干渉計と反射鏡の感度は, 干渉計と反射鏡の距離が変化しても一定であることを確認した.

(3) 反射鏡上の反射点数を増加させると感度が反射点数に比例して向上し, 測定值のバラつきが減少することを 確認した.

（4）一般に採用されている長尺平面鏡を用いる方法と，開発した測定法とを用いて，マシニングセンタのテーブ ル送り時に発生するロールを同時測定し，ほぼ同一の結果を得た。

\section{謝 辞}

本研究は, 経済産業省の平成 18 年度地域新生コンソーシアム研究開発事業のフォロー研究として実施したもの であり，お世話になった経済産業省や (財) 石川県産業創出支援機構を始めとする関係各位に感謝申し上げます.

\section{文献}

Agilent Technologies, Optics and laser heads for laser interferometer positioning systems, 2009 02/09 5964-6190 E.

Fan, K. C., Chen, M. J. and Huang, W. M., A six-degree-of-freedom measurement system for the motion accuracy of linear stages, International Journal of Machine Tools and Manufacture, Vol.38, Issue 3(1998), pp.155-164.

今井 登, 清水伸二, 工作機械直進テーブル運動精度の 6 自由度同時測定法の提案, 精密工学会誌, Vol.67, No.1(2001), pp.126-130.

JISB6336-2, マシニングセンタ-検査条件- 第 2部:立て形及び万能主軸頭を持つ機械の静的精度(垂直 Z 軸) (2002), 日本工業規格.

中藪俊博, 森 基, 滝田 敦, 岡地正博, 今井秀孝, レーザ干渉法によるローリング測定システムの開発, 精密工学 会誌, Vol.61, No.2(1995), pp.253-257.

中藪俊博, 岡地正博, 今井秀孝, 若林 剛, ローリグ測定用簡易型レーザ干涉計の開発, 日本機械学会松山市講演 論文集, No.025-2(2002), pp.259-260. 
Nakayabu, Okada, Asakawa, Kanamaru, Hirosaki, Tamura, Yachi, Shimizu, Kawara and Amaya, Transactions of the JSME (in Japanese), Vol.80, No.811 (2014)

中藪俊博, 岡地正博, 今井秀孝, 平尾政利, 浅川直紀, 谷内秀夫, 清水昭裕, 天谷浩一, 廣崎憲一. 田村陽一, ロー ル測定用高性能レーザ干渉計の開発，日本機械学会論文集，C 編, Vol.75, No.756(2009), pp.151-158.

Okaji, M. and Imai, H., A practical measurement system for the accurate determination of linear thermal expansion coefficients, Bulletin of NRLM, Vol.34, No.1(1985), pp.46-51.

岡地正博, ローリング測定用レーザ干渉計, 精密工学会春季大会学術講演論文集(1986), pp.479-480.

谷村吉久, 加藤 敬, 角度アライメントの 3 成分が測れるオートコリメータ用反射装置, 精密工学会誌, Vol.53, No.6(1987), pp.896-901.

\section{References}

Agilent Technologies, Optics and laser heads for laser interferometer positioning systems, 2009 02/09 5964-6190 E.

Fan, K. C., Chen, M. J. and Huang, W. M., A six-degree-of-freedom measurement system for the motion accuracy of linear stages, International Journal of Machine Tools and Manufacture, Vol.38, Issue 3(1998), pp.155-164.

Imai, N. and Shimizu, S., Simultaneous measuring method of linear motion error of the machine tool table, Journal of JSPE, Vol.67, No.1(2001), pp.126-130(in Japanese).

JISB6336-2, Test condition for machining centres -Part2, Japanese Standards Association (2002), (in Japanese).

Nakayabu, T., Mori, H., Takida, A., Okaji, M. and Imai, H., Development of practical measurement system for rolling by means of laser interferometry, Journal of JSPE, Vol.61, No.2(1995), pp.253-257(in Japanese).

Nakayabu, T., Okaji, M., Imai, H. and Wakabayashi, G., Development of a versatile laser interferometer for measurement of rolling, Proceedings from JSME Meeting in Matsuyama, No.025-2(2002), pp.259-260(in Japanese).

Nakayabu, T., Okaji, M., Imai, H., Hirao, M., Asakawa, N., Yachi, H., Shimizu, A., Amaya, K., Hirosaki, K. and Tamura, Y. Development of a high-performance laser interferometer for roll measurement, Transactions of the JSME, Series C, Vol.75, No.756(2009), pp.151-158(in Japanese).

Okaji, M. and Imai, H., A practical measurement system for the accurate determination of linear thermal expansion coefficients, Bulletin of NRLM, Vol.34, No.1(1985), pp.46-51.

Okaji, M., Interferometer for measurement of roll, Proceedings from JSPE Spring Meeting (1986), pp.479-480(in Japanese).

Tanimura, Y. and Kato, T., Reflection device of autocollimator for measuring three components of angular alignment, Journal of JSPE, Vol.53, No.6(1987), pp.896-901(in Japanese). 